\title{
METHODOLOGICAL PERFORMANCE EVALUATION BY TEACHERS IN PRESCHOOL EDUCATIONAL INTITUTIONS
}

Dr. Natalia Anatolyevna Stepanova, Nosov Magnitogorsk State Technical University, Russian Federation E-mail: professor_stepanova@mail.ru

Dr. Lilia Nailevna Sannikova, Nosov Magnitogorsk State Technical University, Russian Federation E-mail: sannikova.lilia@rambler.ru

Dr. Nataliya Ivanovna Levshina, Nosov Magnitogorsk State Technical University, Russian Federation E-mail: levshina.n.i@yandex.ru

Dr. Svetlana Nikolayevna Yurevich, Nosov Magnitogorsk State Technical University, Russian Federation E-mail: s.n.yurevich@gmail.com

Dr. Galina Vyacheslavovna Ilyina, Nosov Magnitogorsk State Technical University, Russian Federation E-mail: ilyina.galina@inbox.ru

ARTICLE INFO

Original Research

Received: March, 15.2018.

Revised: May, 09.2018.

Accepted: May, 15.2018.

doi:10.5937/ijcrsee1802067A

UDK

373.2.022

$371.13 / .15$

Keywords:

preschool education, preschool educational institution,

methodological work, methodological performance evaluation,

assessment technology,

implementation charts.

\section{A B S T R A C T}

The article describes a technology of teachers' assessment of methodological performance as an aspect of preschool educational establishment management. Theoretical methods have been the major problem research methods: analysis of normative legal documents; theoretical and methodological analysis; system analysis; design approach; empirical methods: ascertaining experiment, questionnaire survey, interviews with preschool teachers. The authors have determined a theoretical and methodological framework for the study of the problem of effective methodological performance evaluation by teachers in preschool educational institutions; principles of implementing this technology have been proposed. In addition to the methodological performance evaluation technology by teachers, which includes research and monitoring stages and a decision-making stage, the authors have developed implementation charts for assessing methodological performance by teachers in preschool educational establishments and defined the criterion and level characteristics of methodological performance. Carrying out the procedure for assessing methodological performance in a PEI will ensure support for the organization's processes, as well as facilitate a transfer of the organization from a merely functioning state to the state of dynamic development.

(C) 2018 IJCRSEE. All rights reserved.

\section{INTRODUCTION}

The relevance of this study is determined by insufficiently developed technological support for the process of methodological performance management in a preschool educational establishment, a lack of scientifically based diagnostic tools to involve teachers of

Dr. Natalia Anatolyevna Stepanova, Nosov Magnitogorsk State Technical University, Russian Federation

E-mail: professor_stepanova@mail.ru

\section{c) (†) $\ominus$}

This work is licensed under a Creative Commons Attribution - NonCommercial - NoDerivs 4.0. The article is published with Open Access at www.ijcrsee.com preschool educational institutions (PEIs) to assessing the methodological performance.

The primary objective of the state educational policy of the Russian Federation within the framework of implementing the federal state educational standard for preschool education and the 'Teacher' occupational standard is to provide the up-to-date quality of preschool education (Order No. 544n. (2013)).

The quality of preschool education is in turn ensured by the quality of teaching staff, their respective training in the process of higher education, in the process of further training and proficiency enhancement of education officers.

One of such forms of work is methodological work in a preschool educational institution. Methodological work holds a spe- 
cific place in a PEI management system and is closely related to major purposes and core management functions. Its pivotal role is manifested in promoting the human element teachers' personalities and creative activities. The main reference points for methodological work in a kindergarten are: a guided quantum growth of each teacher's professional skills; an increase in integration capabilities of the whole team; a quality of the educational process in a PEI.

Achieving these benchmarks is impossible without quality management of methodological performance in a PEI. Methodological performance is inextricably linked with consumers of this educational service, that is, the teachers of a PEI, their needs, and also the degree of their satisfaction. The current state educational policy is aimed at "inclusion of educational service consumers in assessing the quality of these services". This is evidenced by legal and organizational documents of recent years. However, despite considerable achievements in terms of theoretical development of the problem of assessing the general education quality, there are no technologies for assessing methodological performance by teachers as an aspect of preschool educational establishment management in PEI practice; criterion and diagnostic tools for teachers' assessment of this type of activity have not been elaborated either. This fact determines the relevance of the specified problem - the need for technological support for the process of methodological performance assessment by teachers of a preschool educational establishment as an aspect of PEI management.

The desire to adjust this difference has impelled the authors to develop a technology for methodological performance assessment by teachers in a PEI, which determined the main goal of the research.

The purpose of the research is to develop a technology for assessing methodological performance by teachers as an aspect of preschool educational institution management.

The research objectives include:

- to reveal the state of the problem in scientific literature and practice;

- to describe the technology of teachers' assessment of methodological performance as an aspect of PEI management in the form of an appraisal practice program that would reveal common tasks, logic and content of appraisal stages;

- to develop implementation charts and criterion and diagnostic tools for assessing methodological performance by teachers as an aspect of PEI management.

The current state policy in the field of preschool education is aimed at arranging conditions for ensuring the quality of all structural components of preschool education, including such a component as teaching staff. A competently organized methodological work contributes to the perfection of their professionalism and expertise. This is evidenced by legal and organizational documents of recent years.

The Federal Law 'On Education in the Russian Federation' detailing the concept of 'Management of the Educational System' (Article 89, Clauses 2.6, 2.7) includes, in addition to 'state regulation of educational activities' (licensing procedures for educational activities, state accreditation of educational activities, state control (supervision) in the field of education), 'independent evaluation of the quality of education, public and nongovernment professional accreditation' (FZ$273,2012)$. Thus, it is worth noting that in the educational policy, there is a shift in emphasis towards supporting the implementation of evaluation procedures that assess the quality of education through public and professional communities. 'Inclusion of consumers of educational services in the assessment of the educational system activity' becomes topical (the Government Program of the Russian Federation 'Development of Education for 20132020’)

An important document is undoubtedly 'Recommendations for the use of tools in public and professional assessment of the preschool education quality' developed by the Federal State Autonomous Institution 'Federal Institute for Education Development' (FSAI FIED) as part of activities in the field of 'Modernization and implementation of a modern evaluation system and improving the quality of preschool education in preschool educational institutions in accordance with the federal educational standard for preschool education as part of support of development programs of regional municipal preschool education systems' (MES RF Letter No. 0100-05/541. 2015). The authors of the recommendations defined a mechanism that presupposes a two-phase quality assessment system, where self-evaluation of a PEI acts as a first step (first phase), including teachers' assessment of methodological performance in a PEI.

Attempts to solve the problem of assessing the quality of various life activity structures of educational institutions are being undertaken today by both theoretical scientists 
and pedagogical practitioners.

The theoretical foundation of the research is constituted by:

- Theoretical developments in the field of methodological work organization in an educational institution (Ezopova, 2003; Mayer, 2002; Potashnik and Moiseev, 1997; Slastenin and Podymova, 2007; Taranova, 2012; and others);

- Theoretical developments in the field of preschool education quality management (Bagautdinova et al., 2015; Bogoslovets and Mayer, 2013; Koroleva, 2014; Safonova, 2004; Svatalova and Yakovleva, 2015; Stepanova et al., 2017; Taratukhina and Shirokova, 2013; and others).

Analysis of psychological and pedagogical literature has shown that today methodological work is construed as "part of professional pedagogical (professional managerial) activity, within the framework of which theoretical products that ensure pedagogical or administrative actions are mastered, examined and developed' (Slastenin and Podymova, 2007).

Penetration of management theory into preschool education, division of subjects and objects of PEI management, definition of managerial activity areas from in terms of object (personnel management (human resources), material and technical base management, etc.) have made it possible to define methodological work as one of the managerial activity areas, as a special activity in which the actors ensure coherence of teachers' joint methodological activities and their focus on achieving educational goals through planning, organization, management and monitoring (Bagautdinova et al., 2015; Bogoslovets and Mayer, 2013).

The object of research is methodological work as an aspect of educational institution management, as an interconnected set of elements ('interrelated measures, actions and efforts') that in conjunction reveal the consistency of the methodological activity of a PEI teaching staff and are aimed at ensuring sound preschool education (Bagautdinova et al., 2015). A leading part is assigned to methodological work in a PEI in the process of intensifying pedagogical work, developing teachers' professional competence and activating interaction with parents (Stepanova et al., 2017).

An important management function is quantity and quality record and result monitoring. Since management process takes place in a continually changing environment and is characterized by varying degrees of uncertain- ty, monitoring could prove how much administrative action has reached the desired goals, what adjustments managerial decisions need and whether they do at all; which aspects of management 'sink', and which require further development and improvement. In the management theory, what is considered the most optimal is monitoring exercised through feedback, which provides quantitative and qualitative assessment of collective performance and an institution's performance record (Svatalova and Yakovleva, 2015). Thus, it can be concluded that effectively organized monitoring is primarily focused on solving strategic tasks and on eventual deliverables and should be simple, evident and convincing for each agent. In addition, the effectiveness of the monitoring managerial function is determined by its compliance with the requirements that the modern management theory has developed, namely, how operational, transparent and objective it is.

The scope of research is assessment by teachers of methodological performance in a PEI.

When solving the problem of assessing methodological performance in PEIs, according to the authors, it is appropriate to consider the monitoring function as a reference point of the management cycle linking it to the analysis and planning functions since control is the primary way of feedback and, therefore, a means of obtaining information with reference to which management process is carried out.

The concept of 'methodological performance in a PEI' does not have an unambiguous definition. The authors proceed from the fact that researchers (Safonova, 2004) consider the quality of education as satisfying the needs of consumers for educational services, its compliance with certain standards or specifications.

A definition proposed by Potashnik and Moiseev, (1997: 33) is essentially valuable in this context; when interpreting it, one can note that methodological performance is a relationship of a goal and a result as a measure of achieving goals, while goals (results) of methodological work are given only operationally and predicted in the area of teachers' potential development. At the same time, he points to the need to evaluate 'at what price (at the cost of what losses, efforts) these results are achieved. It is either the absence or minimization of negative consequences in methodological work organization, that is, in all cases, it does not imply achieving any good, but rather the maximum possible result with baseline 
minimum labor, energy, time, etc. cost; in other words, we are referring to optimal results'.

Thus, methodological performance, according to this author's concept, is 'a ratio of a predicted goal and a result' (Potashnik and Moiseev, 1997: 34). Moreover, when ascertaining methodological performance, two points should be taken into account: first, the thesis that methodological performance, as a certain phenomenon and attribute of the educational process, has a design nature, that is, it can and should be the subject of designing work of any management actor (from a teacher to the head of a PEI); second, it is the use of forecasting method that (unlike any other similar states: foreshadowing, guessing, foresight, foretelling, anticipation, etc.) is a scientific method that can be learned (Potashnik and Moiseev, 1997: 34).

Quality is a complex concept. In this regard, methodological performance is a complex characteristic reflecting the effectiveness of all aspects of methodological work: developing a strategy, planning, organizing and directing this process, encouraging teachers, monitoring and correcting their methodological activities, etc. (Mayer, 2002). The most important component of the whole quality system of methodological work is the product quality. The quality of methodological products is a component and a consequence of performance; it is determined by teachers' proficiency level in a PEI. It is important that the formation of product quality begins at the stage of its planning (Koroleva, 2014).

From the standpoint of qualimetry and system characteristics of methodological work, methodological performance is understood as a set of properties that meet the needs of participants in methodological work (that is, teachers) and the requirements of standardized documents.

Based on the analysis of papers in the field of education quality management (Bagautdinova et al., 2015, Koroleva, 2014; Stepanova et al., 2017; Taranova, 2012; Taratukhina and Shirokova, 2013, etc.), the authors have defined the structure of methodological performance:

- the quality of methodological deliverables in a preschool educational institution (teacher satisfaction with advanced training);

- the methodological performance as a supporting process for teachers (teacher satisfaction with methodological work organization in the PEI, quality of forms and methods of methodological work, variability of methodological work forms);
- the quality of conditions created in a preschool educational establishment for effective methodological work organization (in terms of personnel (in the person of senior teacher), material, technical, informational, didactical aspects, etc.), openness of the methodological work system, its interaction with other social institutions.

The process of methodological performance management is considered as special control organized and aimed at achieving well-defined results of this type of activity predicted with a possible degree of accuracy. Since methodological performance management also includes managerial activities (goal-setting, forecasting, design, organization, monitoring), the quality management of methodological work should be viewed as a systematic, integrated and organized working process aimed at continuous quality improvement (Ezopova, 2003; Mayer, 2002).

For this research, the core thesis of qualimetric approach on recognizing the feasibility of quantitative measurement of both any individual properties and their combinations, including complex or integral quality, which methodological performance is, has been important. An evaluation in general terms is judgments about a particular phenomenon presented in a qualitative or quantitative form. The concepts of 'assessment' and 'evaluation' are fundamental in measurement theory and can be used in pedagogical activity (Taranova, 2012; Taratukhina and Shirokova, 2013).

The essence of qualimetric approach is manifested in its principles. The principles of qualimetric approach include the following: informativeness, integrity, optimality, accuracy, conclusiveness, producibility, accessibility and others. The principle of producibility has served as the basis for developing a technology for assessing methodological performance by teachers as an aspect of preschool educational institution management.

The academic literature analysis has allowed the authors to state the problems that a preschool educational institution must solve in order to ensure high methodological performance:

1. To learn to correctly forecast, design, simulate qualities (properties) of teacher training that a PEI expects to receive 'at the output' as a result of advanced training process in the methodological framework, that is, to determine the goals of methodological work and the quality of methodological work required in the future.

2. To achieve and to maintain a required 
level of methodological performance, timely preventing undesirable deviations from it.

3 . To improve methodological performance, bringing it in line with demanding requirements of regulatory documents. Improving methodological performance and any new properties emerging therein are possible only through an innovative process.

4. To identify and assess factual methodological performance, its compliance with the required standards.

Development of methodological performance in a PEI is possible only if the system is evaluated for efficiency, and its further development is predicted.

\section{MATERIALS AND METHODS}

Theoretical methods were essential methods to investigate this problem: analysis of regulatory documents to prove the relevance of the formulated problem; theoretical and methodological analysis to determine reference points of this study; system analysis for a holistic examination of the scope of research; method of design to develop a technology for assessing methodological performance by teachers as an aspect of preschool educational institution management. To confirm the relevance of the problem, empirical methods were used: ascertaining experiment, questionnaire survey, interviews with PEI teachers.

The questionnaire included questions concerning conditions created in the PEI for teachers' methodological work, their participation in various forms of methodological work, as well as the issue of involving teachers in assessing methodological performance in the PEI.

In course of the questionnaire survey, teachers were asked to assess their satisfaction with the methodological performance in the PEI on a scale from one to three: a) fully satisfied; b) partially satisfied; c) not satisfied. The respondents filled out questionnaires by themselves.

The results obtained during the first set of the ascertaining experiment confirm that personnel development is carried out both in the preschool educational establishment and beyond it, covers self-educational activity of teachers, their preparation for certification, includes exchange and communication of pedagogical experience, is aimed at addressing tasks of the educational institution and professional activities of teachers. This is evidenced by findings of the questionnaire and interviews with teachers.

The second set of the ascertaining experiment was aimed at identifying the existing mechanism for assessing the methodological performance. With the help of questionnaires and interviews, the authors were able to establish: senior teachers assess the methodological activities of teachers. But the procedure for assessing the quality of planning and organization of methodological work by teachers of preschool educational institutions has not been properly organized. At the same time, all senior teachers realize the importance of feedback and would like to have information about the quality of methodological work management, but almost none of them take measures for this since there are no tools for such work.

Thus, identifying actual state of things in terms of the problem under consideration in science and of preschool educational institutions has served as the basis for developing a technology for assessing methodological performance in a PEI.

In this research, teachers of preschool educational institutions were subjects of methodological performance assessment.

The sample size includes 108 people. These are teachers and experts of preschool educational organizations in Magnitogorsk.

Among them:

- 57\% have higher education;

- $18 \%$ have incomplete higher education;

- $25 \%$ have secondary pedagogical education.

Of the total number of respondents:

$-52 \%$ of respondents have worked with children for over 20 years;

- $28 \%$ of respondents have worked with children for over 10 years;

$-20 \%$ of respondents have worked with children up to 10 years.

\section{RESULTS}

Development of a technology for assessing methodological performance by teachers as an aspect of preschool educational establishment management has become the study outcome. The technology is a program (algorithm) of evaluation activity revealing common tasks, logic and content of evaluation stages. The technology for assessing methodological management in a PEI includes three stages: the research and monitoring stages and the decision-making stage (Table 1). 
(IJCRSEE) International Journal of Cognitive Research in Science, Engineering and Education Vol. 6, No. 2, 2018.

Table 1. Technology of methodological performance assessment in a PEI

\begin{tabular}{|c|c|c|}
\hline Stage & Objectives at the stage & Scope of the stage \\
\hline $\begin{array}{l}\text { First stage: } \\
\text { research }\end{array}$ & $\begin{array}{l}\text { Laying down quality assessment } \\
\text { parameters for the management } \\
\text { object (methodological work). }\end{array}$ & $\begin{array}{l}\text { This stage is associated with defining the structure and } \\
\text { array of criteria, quality indicator constants, levels and } \\
\text { methods for calculating integrated assessment. }\end{array}$ \\
\hline $\begin{array}{l}\text { Second stage: } \\
\text { monitoring }\end{array}$ & $\begin{array}{l}\text { Measuring the results of the } \\
\text { management object's activity } \\
\text { (methodological work). }\end{array}$ & $\begin{array}{l}\text { The stage is associated with integrated assessment of } \\
\text { methodological performance on the basis of a } \\
\text { knowledge-based chart. Qualimetric monitoring is used } \\
\text { to ensure transformation of information about } \\
\text { methodological deliverables in educational institutions, } \\
\text { its structuring and improvement (development). }\end{array}$ \\
\hline $\begin{array}{l}\text { Third stage: } \\
\text { decision-making }\end{array}$ & $\begin{array}{l}\text { Managerial influence on the } \\
\text { monitoring result involves } \\
\text { transition to other management } \\
\text { functions (analysis, forecasting, } \\
\text { etc.), drawing conclusions and } \\
\text { formulating proposals for further } \\
\text { development of methodological } \\
\text { work. }\end{array}$ & $\begin{array}{l}\text { This analysis stage is transitional to the planning } \\
\text { function: the conclusions and proposals made in its } \\
\text { course are included into an analytical justification for } \\
\text { the planning documents. } \\
\text { Depending on the conclusions and proposals made, the } \\
\text { goals and objectives of methodological work for the } \\
\text { next life period of a PEI are formed. Based on the goal } \\
\text { setting results, necessary measures and terms for their } \\
\text { implementation are developed. }\end{array}$ \\
\hline
\end{tabular}

At the first stage, a system of criteria and indicators is developed, levels and methods for calculating an integrated assessment are identified, as well as mechanisms for measuring parameters (criteria and indices) characterizing methodological performance in a PEI.

The second stage is monitoring. The stage is connected with an integrated assessment of methodological performance on the basis of an implementation chart.

The task is to assess the manifestation degree of methodological performance indicators with the help of evaluation forms, that is, implementation charts that serve as technological support for the methodological performance assessment process.

The authors have developed implementation charts for assessing methodological performance in a PEI (Table 2). It is possible to use them on paper, but a more effective way would be to develop software to assess methodological performance. 
Table 2. Implementation chart for methodological performance assessment in a PEI

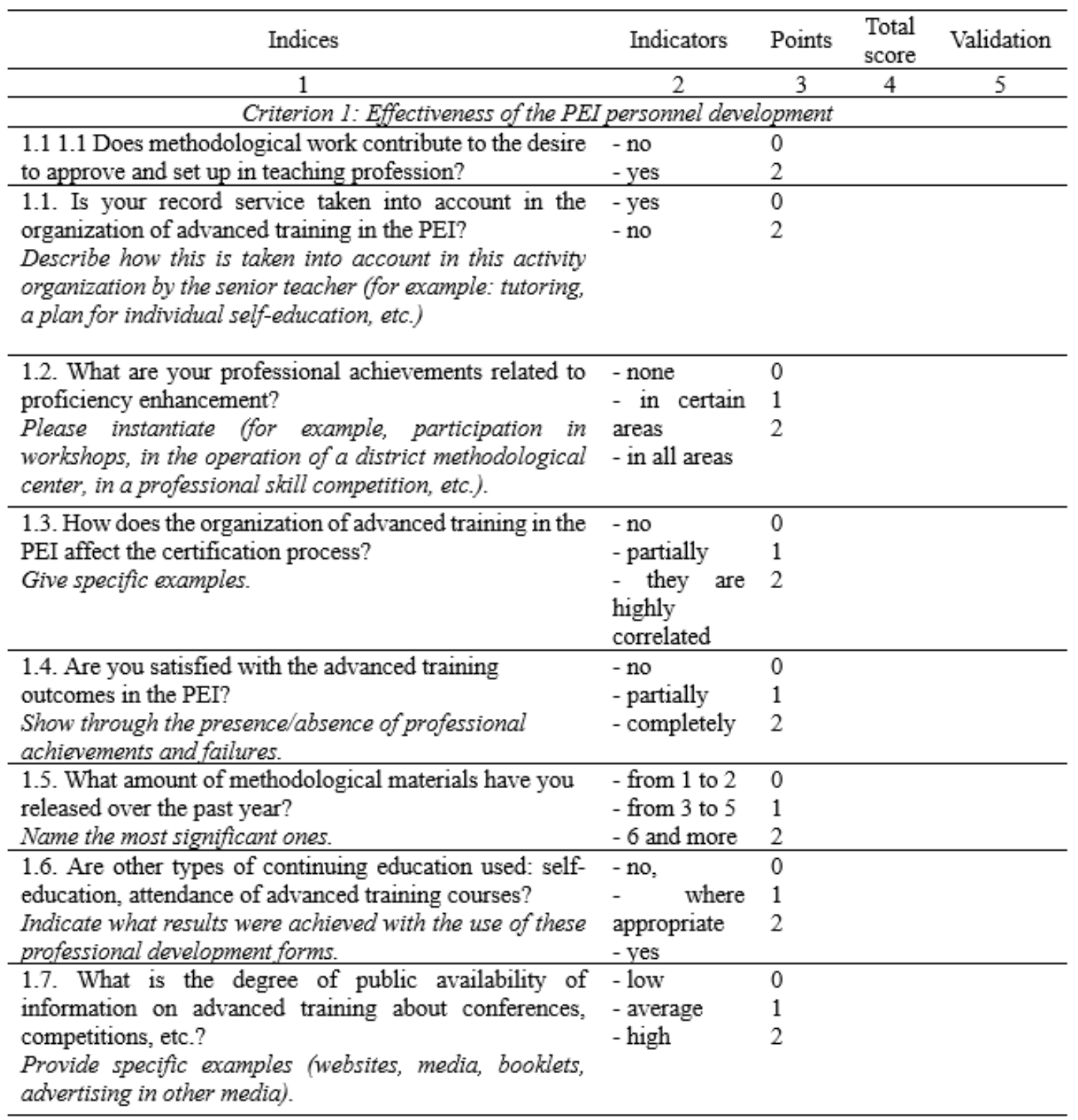




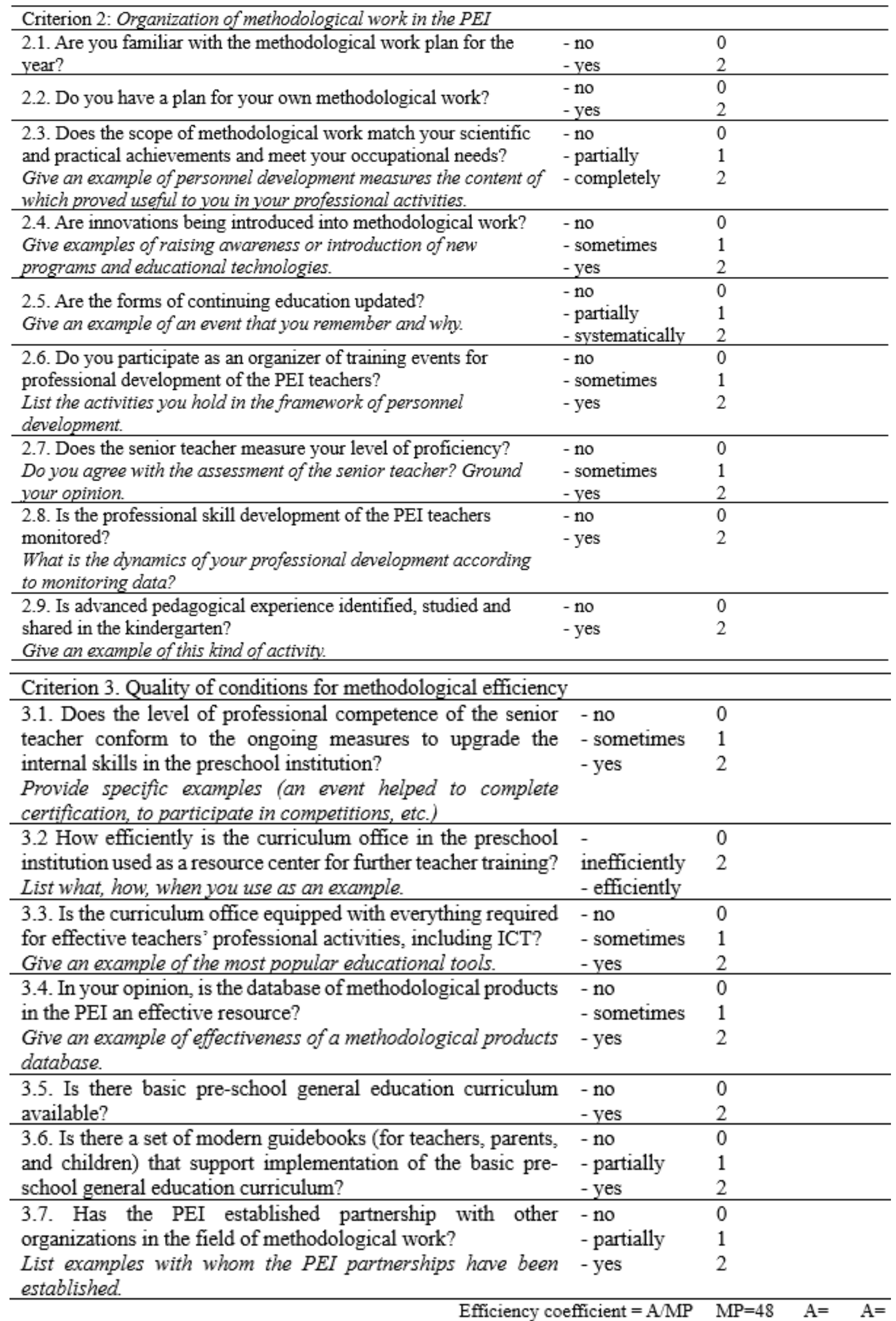


The third stage is decision-making. At this stage, based on monitoring information, analytical materials and public reports are prepared. Analytical materials are a form of a generalized presentation of the education quality evaluation findings, whereby individual evaluations of participants may not be mentioned at all or used as solitary instances. Analytical materials can be designed as information graphics or as a text document. Examples of textual analytical materials are public reports and statements on methodological deliverables and prospects of educational institution and system activities.

\section{DISCUSSIONS}

The 'Teacher' occupational standard clarifies the concepts of 'criteria and indices' and introduces the concept of 'indicator'. "Criteria for quality assessment are an aggregate attribute that serves as a basis for quality assessment formation. An index is a characteristic of a teacher's activity that is observable and measurable, indicative of the effectiveness and quality of their performance and enabling to calculate the quality indicator upon a selected criterion. An indicator is objective information, normally quantitative, indicative of a teacher's performance results in a certain period according to a certain criterion" (Order No. 544n. (2013)).

In this paper, the following criteria have been singled out:

- quality of methodological deliverables;

- quality of methodological support process for teachers;

- quality of methodological environment.

Each criterion, therefore, is revealed through a system of indices and indicators forming criterion and diagnostic tools for assessing methodological performance.

With respect to teachers' assessment of methodological performance, the authors have applied the following principles:

- conformity of quality estimation criteria with factual methodological activity;

- simplicity of calculations;

- measurability of indicators;

- moderate quantitative representation of indicators.

Measurement of parameters characterizing of methodological performance according to the degree of their compliance with the requirements of regulatory documents (scaling) is the prominent mechanism. Scaling is the simplest and most accessible measurement model. It assumes that the procedure for determining a parameter compliance with the requirements of regulatory documents is reflected in a verbal, descriptive form:

- complies (yes);

- partially complies (in part);

- does not comply (no).

The composite scores for each of the criteria, for a group of indicators, for all indicators characterizing methodological performance should be compared with a permissible range of scores. A mathematical model for processing the measurement of parameters characterizing the quality of preschool education ensures the highest objectivity based on scores.

Conclusion on the methodological performance level in a PEI is drawn by comparing the scores obtained through the following level scale:

- from 0 to 16 points - a low level;

- from 17 to 33 points - an allowable (average) level;

- from 34 to 48 points - an optimal (high, creative) level.

The efficiency coefficient is a ratio of the actually scored number of points to the maximum possible. In this case, the levels are defined as follows:

level;

- from 0.00 to 0.33 - a critical (low)

- from 0.34 to 0.69 - an allowable level;

- from 0.70 to 1.00 - an optimal level.

When filling in an implementation chart for assessing methodological performance in a PEI, attention should be paid to the following methodological recommendations.

1. An implementation chart for assessing methodological performance in a PEI has been developed on the basis of federal and regional regulatory acts and other documents that specify requirements for the educational process implementation.

2. In order to monitor methodological performance, it is suggested that the chart should be filled in by the same group of educators. This will make it possible to obtain results in the dynamics of their development, to compare them and to make timely correction of processes within the framework of methodological work.

3. When filling in the implementation chart, it is possible to introduce a 'weighting coefficient'. The implementation chart is filled in as follows: the points related to a selected criterion are multiplied by the 'weighting co- 
efficient', and the resulting product is indicated in the column 'Actual score'.

4. In the column 'Validation', a reference can be given to various local regulatory acts and other documents that regulate activities related to the organization of methodological work in a preschool educational institution (PEI):

- orders (on establishing a Coordination Council for the PEI development program implementation, on convening working groups for implementation of the Federal State Educational Standard in preschool education, on approval of an educational establishment curriculum to improve the proficiency level of executive and teaching employees, on exercising internal control over the Federal State Educational Standard implementation; on modifications to job descriptions of executive and teaching employees; on approval of new or revised job descriptions; on approval of a methodological work plan, etc.).;

- regulations (on working groups, on the internal audit procedure, etc.);

- agreements (to cooperate with social actors, etc.);

- plans (methodological work, proficiency enhancement for executive and teaching employees, etc.);

- minutes (meetings of the PEI council, the governing council, the supervisory board, meetings of agencies where the issues of introducing amendments and additions to the content of Regulations and Procedures, meetings of the teachers' council, the teacher-parents meetings, etc. were considered);

- lists (of documents included in the bank of normative and legal documents at the federal and regional levels, referenced information resources with e-mail addresses indicated, etc.);

- information certificates (on the quantitative and qualitative composition of teaching staff indicating the ratio of executive and teaching employees who have received further training, on the costing calculation and formation mechanism necessary for implementation of principal vocational educational programs, on the PEI funding standards; on the amount of additionally raised financial resources; on the PEI equipment; on compliance of the material and technical base with the principal educational program implementation; on staffing level of the curriculum office, etc.);

- website URLs and e-mails of the PEI;

- miscellaneous.

The methods used in measuring the parameters characterizing methodological per- formance are as follows: analysis (of data, documentation, etc.); expert reviews; interviews; study of methodological activity products; data collection, formalization, grouping, processing, etc.

Depending on the conclusions and proposals made, goals and objectives for methodological work for the next life period of a PEI are formed.

\section{CONCLUSIONS}

Methodological performance is an important performance indicator of a preschool educational establishment. Methodological performance cannot be effectively managed without feedback, without studying consumer satisfaction with this educational service, without methodological performance evaluation by teachers as an aspect of preschool educational institution management. The analysis of scientific literature and regulatory documents indicates the need to engage consumers of services in assessment of their quality. However, the ascertaining stage of the experiment has shown the lack of a technology available for methodological performance assessment by teachers as an aspect of preschool educational institution management.

Development of a technology for teachers' assessment of methodological performance as an aspect of preschool educational institution management was the goal of the research.

The technology has been developed taking into account the Russian Federation legislation and allows maximum recognition of teacher methodological activity specifics in a PEI, provides an opportunity for monitoring studies to evaluate methodological performance and to design a system of methodological assistance and support based on the results obtained.

The technology is an evaluation activity program that reveals common tasks, logic and content of evaluation stages.

The first stage - research- is related to defining criteria, performance indices, quality indicators, levels, methods for an integrated assessment of methodological performance as an aspect of preschool educational institution management. Developed on the basis of federal and regional regulatory acts applying requirements to the educational process implementation, the criterion and diagnostic tools reflect the essential features of methodological activity; they also meet the requirements of 
measurability indicators, moderate quantitative composition of indicators, and simplicity of calculations. The criterion and diagnostic toolkit presented in the form of a knowledgebased chart serves as a mechanism for assessing methodological performance in a PEI.

The second stage - monitoring - is related to measurement of methodological deliverables and to an integrated assessment of methodological performance on the basis of a knowledge-based chart. The knowledge-based chart serves as a basis for monitoring methodological performance. Filling in the chart by the same group of teachers makes it possible to obtain results in the dynamics of their development, to compare them and make a timely correction of processes in the framework of methodological work.

The third stage - decision-making - is transitional to the planning function: the conclusions and proposals made in its course are included into an analytical justification for the planning documents. Assessment of methodological performance in a preschool educational establishment by teachers gives a clear picture of the teachers' satisfaction level with the organization and content of methodological work, displays problems and potential of methodological work in the establishment, and accordingly maps out development options for the preschool educational establishment. On the basis of database collected during the expert evaluation, it is possible to define work priorities and at the same time to reduce efforts to develop quality, while making it foreseeable and feasible.

Application of the technology for methodological performance assessment by teachers as an aspect of preschool educational institution management allows one:

- first, to present systematically the objectives and expected deliverables of the teachers' methodological activity of a preschool institution, requirements to the process and conditions for accomplishment of the objectives;

- second, to increase the role of formalized information in methodological work management in a PEI receiving estimates both for individual and group indicators of methodological work and for its integrated assessment. Unlike verbal information, formalized information is more accurate, less subject to an influence of judgmental factors in its interpretation, can be transformed by mathematical methods, it is easier to systematize, store, and reuse; more specific premised on methodological performance indicators that can act as through parameters for the monitoring, analysis, planning and organization functions;

- fourth, to create an information base for a management actor about the object on the basis of methodological performance assessment.

Evaluation of methodological performance is intended:

- to acquire objective information about the activity state in a PEI;

- to acquire objective information about the activity management state in a PEI as a whole and methodological work, in particular;

- to acquire objective information about the activity state of teachers of different levels (its conditions, process and deliverables) in a PEI;

- to reveal positive and negative trends in teachers' methodological activity;

- to determine the causes for improvement or deterioration in the quality of teachers' methodological activity in different periods of their work.

Methodological performance assessment in a PEI is required in the following cases:

- at the stage of preparing programs for the PEI development and local target programs;

- when summing up the results for certain periods of the PEI operation;

- for making managerial decisions on personnel matters;

- for solving problems associated with the enhancement of a career development system for personnel;

- during certification of teachers.

Carrying out the procedure for assessing methodological performance in a PEI will ensure support for the organization's processes, as well as facilitate a transfer of the organization from a merely functioning state to the state of dynamic development.

It is appropriate to consider methodological performance evaluation as an integral part of the system of assessing the performance of a preschool educational institution and as the most important foundation for solving the problems of preschool education quality management in a preschool educational establishment. 


\section{ACKNOWLEDGEMENTS}

The authors express gratitude to the Department of Education of the Municipal Administration of Magnitogorsk, Chelyabinsk region of the Russian Federation, represented by Natalya Safonova (the Department Head) and Natalya Vladimirovna Dorogina (the Preschool Education Department Head) for the opportunity to study the problem of methodological performance assessment in municipal preschool institutions.

The authors are grateful to the municipal preschool educational institutions of Magnitogorsk for their cooperation.

\section{Conflict of interests}

The authors declare no conflict of interest.

\section{REFERENCES}

Bagautdinova, S. F., Korneshchuk, N. G., Rubin, G. Sh., Starkov. A. N. (2015). Comprehensive quality assessment of the pre-school educational institution activities: monograph. [Комплексная оценка качества деятельности дошкольного образовательного учреждения: монография] $2^{\text {nd }}$ ed., Moscow: FLINTA.

Bogoslovets, L. G., and Mayer, A.A. (2013). Preschool education quality management: methodological manual. [Управление качеством дошкольного образования: Методическое пособие ] Moscow: TC Sfera.

Ezopova, S. A. (2003). Management in preschool education. [Менеджмент в дошкольном образовании] Moscow: Academiya.

FZ-273. (2012). Federal Law of the Russian Federation of December 29, 2012 "On Education in the Russian Federation” [№ 273-Ф3 «Об образовании в Российской Федерации»] http://www.consultant.ru/document/cons doc LAW 140174/

Koroleva, S. V.(2014). Simulation of the process of quality management in pre-school educational organization. [Моделирование процесса управления качеством в дошкольной образовательной организации] Pedagogical Education in Russia, 1, 31-35. http://journals.uspu.ru/attachments/article $/ 556 / \% \mathrm{D} 0 \% 9 \mathrm{~F} \% \mathrm{D} 0 \% \mathrm{~B} 5 \% \mathrm{D} 0 \% \mathrm{~B}$ $4 \%$ D0 $\%$ B $0 \%$ D0 $\%$ B $3 \%$ D0 $\%$ BE $\%$ D $0 \%$ B $3 \% \mathrm{D}$ $0 \% \mathrm{~B} 8 \% \mathrm{D} 1 \% 87 \% \mathrm{D} 0 \% \mathrm{~B} 5 \% \mathrm{D} 1 \% 81 \% \mathrm{D} 0 \% \mathrm{BA}$ $\% \mathrm{D} 0 \% \mathrm{BE} \% \mathrm{D} 0 \% \mathrm{~B} 5 \% 20 \% \mathrm{D} 0 \% \mathrm{BE} \% \mathrm{D} 0 \% \mathrm{~B} 1 \%$ D1\%80\%D0\%B0\%D0\%B7\%D0\%BE\%D0\%B $2 \% \mathrm{D} 0 \% \mathrm{~B} 0 \% \mathrm{D} 0 \% \mathrm{BD} \% \mathrm{D} 0 \% \mathrm{~B} 8 \% \mathrm{D} 0 \% \mathrm{~B} 5 \% 20$ $\%$ D0\%B2\%20\%D0\%A0\%D0\%BE\%D1\%81\% D1\%81\%D0\%B8\%D0\%B8 $2014 \quad 1 \%$ D1\%81 $\% \mathrm{D} 1 \% 82 . \% 2007 . \mathrm{pdf}$

Mayer, A. A. (2002). Reflexive monitoring of the formation of the preschool teacher's professional competence: PhD Thesis (Education): 13.00.08. [Рефлексивный мониторинг формирования профессиональной компетентности педагога дошкольного образования: дис. ... канд. пед. наук: 13.00.08] Barnaul: Barnaul State Peda- gogical University Press.

MES RF Letter No. 01-00-05/541. (2015). Letter of the Ministry of Education and Science of the Russian Federation No. 01-00-05/541 of June 15, 2015. [Письмо Министерства образования и науки РФ № 01-00-05/541 от 15.06.2015] http://uo-udora.ucoz.ru/files/docs/fed/2015-09/ pismo_v_subekty_rf-1.pdf

Order No. $5 \overline{4} \bar{n}$. (2013). Order of the Ministry of Labor and Social Protection of the Russian Federation No. 544n of October 18, 2013 "On the approval of the professional standard 'Teacher (pedagogical activity in the field of preschool, primary general, basic general, secondary general education) (educator, teacher)'. [Приказ Министерства труда и социальной защиты Российской Федерации от 18 октября 2013 г. № 544н г. Москва «Об утверждении профессионального стандарта «Педагог (педагогическая деятельность в сфере дошкольного, начального общего, основного общего, среднего общего образования) (воспитатель, учитель)»] Russian Newspaper. 2013. 18 December. www.rg.ru/2013/12/18/ pedagog-dok.html

Potashnik, M. M., and Moiseev, A. M. (1997). Management of modern school. [Управление современной школой] Moscow: Novaya Shkola.

Safonova, O. A. (2004). Management of the education quality in the preschool educational institution: PhD Thesis (Education). [Управление качеством образования в дошкольном образовательном учреждении: Дисс.... канд. пед. наук.] N. Novgorod.

Slastenin, V. A., and Podymova, L. S. (2007). Readiness of the teacher for innovation activity. [Готовность педагога к инновационной деятельности] Siberian Pedagogical Journal, 1, 42-49. https://cyberleninka.ru/article/v/gotovnost-pedagoga-k-innovatsionnoy-deyatelnosti

Stepanova N. A., Sannikova L. N., Levshina N. I., Yurevich S. N., Chernobrovkin V. A. (2017). Parental Evaluation of Preschool Education Quality: Is It a Problem or an Opportunity? Man in India. Vol. 97(5), 171-185. http://serialsjournals.com/serialjournalmanager/pdf/1499496563.pdf

Svatalova, T. A. and Yakovleva, G. V. (2015). Evaluation of the professional competence of the preschool education teacher in the conditions of introduction of the professional standard of the teacher. [Оценивание профессиональной компетентности педагога дошкольного образования в условия введения профессионального стандарта педагога] Scientific Support of the System of Advanced Training of Personnel, 1(22), 14-19.

Taranova, T. N. 2012. The Essential Feature of the Innovative Instructional Teacher of Culture. [Сущностная характеристика инновационной методической культуры педагога] Modern Problems of Science and Education, 5, http://www.science-education.ru/ru/article/ view? id=7066

Taratukhina, M. S., and Shirokova, N. V. (2013). Criterial and measuring assessment of the quality of professional development of teachers of pre-school educational organizations. In Dissemination of the results of scientific research into the practice of preschool education: a col- 
(IJCRSEE) International Journal of Cognitive Research in Science, Engineering and Education

Vol. 6, No. 2, 2018.

lection of scientific articles on the proceedings of the international scientific and practical conference. [Критериально-измерительная оценка качества повышения квалификации педагогов дошкольной образовательной организации. Диссеминация результатов научных исследований в практику дошкольного образования: сборник научных статей по материалам международной научно-практической конференции.] St. Petersburg: A.I. Herzen. Russian State Pedagogical University Press, pp. 471-477. 